\title{
Impact of the Global Crisis of the Subprime on the Current Stock Price
}

\author{
Samout Ammar \\ Department Methods of Accounting and Finance, University of Sfax, Sfax, Tunisia
}

Email address:

ammarbanq@yahoo.fr

\section{To cite this article:}

Samout Ammar. Impact of the Global Crisis of the Subprime on the Current Stock Price. Journal of Finance and Accounting. Vol. 4, No. 2, 2016, pp. 33-46. doi: 10.11648/j.jfa.20160402.12

Received: February 18, 2016; Accepted: February 25, 2016; Published: March 10, 2016

\begin{abstract}
The present study is therefore based on the determination of the behavior of stock markets during the period of the subprime crisis via the phenomenon of integration and the contagion, the variable used in this study is nothing other than the stock market index. The databases used in this study are daily data of the price of stock indices of 5 developed markets and 5 emerging markets. They have been extracted from the base of the site "Yahoo Finance and economists." These indices cover the period from January 2007 to June 2014, which gives us 2000 Comments by market. The result shows well the significant increase of the coefficient of correlation between stock markets: American, French, Germany and Great Britain during the period of the crisis. We interpret this increase as a proof of the contagion. In the second place, it has tried to apply the theory of cointegration. The results of the cointegration tests show the existence of three cointegrating relationships to the more between the stock markets. The existence of cointegration relationship represents a proof of the contagion and the integration of stock markets. In the third place, it has tried to apply the criterion of the causality between the indices of actions. The result of this test demonstrates the existence of several links of causality between these indices, which confirms the importance of the contagion effect during the crisis.
\end{abstract}

Keywords: Financial Markets, Integration, Contagion, Causality, Crisis

\section{Introduction}

The study of the causes of the crisis is a first debate that is worthy of consideration. This is a very long time that the crisis was announced by many analysts in the light of the debt overhang, public and private, of the level of interrelation of operators and financial "products", of the growing disconnect between financial wealth, and level of wealth produced in the economy. These different analyzes are useful to the understanding of the phenomenon, in search of the responsibilities and solutions.

According to the literature, a financial crisis is regarded by economists as a crisis that affects the stock markets, and the markets of the appropriations of one country or a group of countries... If this financial crisis does in a first time that the financial markets, its aggravation will lead to adverse effects on the real economy, resulting in an economic crisis, or even a recession... This is the case of the crisis of subprime which represents a financial crisis that struck the United States and then propagates to the other countries of the world.

It is surprising that the expansion of the problems of stock markets during the period of the crisis of subprime has caused a growing interest in the study of the behavior of these markets during the crisis via the effects of contagion. The questions that we ask in this work are the following:

What is the impact of the global subprime crisis on the market price?

It is from these findings that we have oriented our work toward the study of degree of interdependence and integration of stock markets during the period of the crisis of subprime represented by the stock indices before and after the crisis.

We will present the main debates associated with the subprime crisis (development of subprime, triggering of crisis of subprime) and in the second place we identify the work who are interested to the factors at the origin of this crisis.

Empirically, we will focus on the impact of the crisis of subprime on stock markets or of ways more accurate the 
contagion of stock markets during the crisis of subprime using the cointegration test, the correlation test and the test of causation

\section{Generality on the Crisis of Subprime}

The crisis of subprime has started on the U.S. real estate market, and then spread to the market of credit risk to achieve the stock markets and the monetary market with a liquidity crisis.

\subsection{The Crisis of Subprime}

The subprimes are credits at risk, characterized by variable rate of interest and high level, which have been granted to low-income households. In consideration of the award criteria less stringent than for conventional credits, the interests were higher. The banks have interest has found solutions to reduce or even eliminate these credit has risk.

Following the events of 11 September 2001, the American government has forced the rate decreases to revive the economy. The real estate market has experienced a real passion, and the banks have granted appropriations estate without worrying about the guarantees.

In the years following the increase in interest rates place certain family in the inability to repay their monthly payments. The houses are put on sale, the real estate market collapses, lower prices, and the banks do not arrive to find their money.

To increase their capacity to lend the American banks have borrowed money to banks around the world, and have slipped these claims on the securities market. To minimize the risk these subprimes were slipped in bundles of actions.

According to IMF (2008), the financial crisis that has developed since the summer of 2007 in the United States is linked to the fluctuations of financial variables such as the volume of issuance of bonds and shares, their courses on the stock exchange, the stock of outstanding credits, the bank deposits and the exchange rate. This crisis has been caused by the excess of indebtedness of households in the United States, the deceleration, and then the fall of the prices real estate. In fact, American households with low income had difficulties to repay the appropriations that had been granted for the purchase of their housing.

\subsection{The Origins of the Crisis of Subprime}

The financial crisis that began in 2007 takes its origin of the monetary policy too accommodative of the U.S. Federal Reserve (Fed) during the years 2000 and financial innovations poorly controlled.

In addition the subprime crisis finds its origin in the case of one of the categories of risks managed by the actors of a market:

- Risk of markets: related to variations in the rates or course of assets (risk of rate, the exchange risk);

- Risks of Credit: related to the reliability of a return, or even of a whole country;
- Risk related to the functioning of the market and to the possibility or not to resell an active (Liquidity Risk).

At another level of analysis, during the recession that followed the bursting of the Internet bubble in 2000-2001, the Fed has lowered its prime rate up to 1 per cent, then the has maintained at a level too low, causing a monetary creation too high and a swelling of bubbles on the real estate markets and on the raw materials. In addition, the American government has put in place a policy of accession to the property which has encouraged banks to make loans to households in reality not creditworthy.

In 2006, the EDF has increased its rate Director of $1 \%$ to $5 \%$ in order to reduce the growing inflationary. This increase in the rate director has caused a deflation of the U. S. housing bubble of the years 2000, and resulted in a higher monthly payments of reimbursement of real estate credits (credits often being at variable rates).

According to $\operatorname{IMF}(2008)$, in $70 \%$ of loans granted in the USA Today, a third person makes the intermediate, a "mortgage broker", which works not for the borrower but for the bank and it is in its interest to convince the customer to take a loan which will benefit more from the bank to itself. For example, if a customer is eligible for a loan classic, but that it is more profitable for the bank to grant him a loan subprime, the broker will convince him, even if it is not profitable and it will affect a kind of bribe called "premium". As long as the house is worth more than the debt, it ready. It is the case of $2 / 3$ of the African Americans who have contracted a loan subprime. The brokers provide loans to customers, knowing very well that they will be unable to repay.

\section{Financial Market and Contagion}

The contagion is the increase in the probability of a crisis in a country following the advent of a crisis in another country. The spread is measured in terms of the correlation between the financial markets. The basic assumption is to test whether or not the spread changes before or after the crisis (King and Wadhwani, 1990). In addition, Forbes et al., (2000), the contagion between fellowships may designate the co-movements and the independence of the main international scholarships. It is, in effect, a reality of all days, since the stock markets are more and more independent. This interdependence can be due to human behavior, since an investor can act and to position itself as a function of fluctuations in the local market as well as according to the opportunities related to the action on other international markets, but their interdependence can also be associated with the degree of the correlation between their fundamental.

In addition, this interdependence is reflected by a strong correlation between the stock indices often more explicit in the period of the stock market crisis, to the extent that any shock affecting a reference exchange can affect the other stock indices.

Masson (1998 and 1999) has identified three factors of contagion. 
- The first factor is equated to an effect of the Monsoon. According to this factor of the countries undergo simultaneous crises due to a common shock (decline in the price of oil, rise in American interest rates, compelled to comply with the prudential ratios in Japan...) which generates a withdrawal of funds outside of the emerging countries. This shock, random, affects so similar a set of emerging countries, without there being first affected country.

- The second factor is related to interdependencies "normal" between countries. According to this factor of countries are affected because of the existence of a crisis elsewhere because of trade and financial links that existed between the country before the crisis.

- The third factor: pure contagion. According to this factor if none of the previous factors cannot justify the crises in series, the agents withdraw their funds in other countries in a movement of panic not justified by economic links.

In agreement with Forbes and Rigobon (2002), there is contagion when the co-movements of the markets are significantly more important during the crisis, for example because of the behavior of international investors

In another registry of analysis, the stock markets have been known since the end of the years 80 an unprecedented boom. The Dow Jones has increased in 1987 by $250 \%$ compared to its level in 1982 and he crossed the bar of 11700 at the beginning of the year 2000. The awards for French and German have at least more than doubled between 1994 and 1999 , indicating that this efflorescence has been common for several awards. What is more, these similarities between the stock dynamics are the most remarkable during the periods marked by strong turbulence. For example, in October 1987, the Dow Jones has lost $22.6 \%$ in one night, exchanges the most important are the followed. More recently, the French stock exchange has suffered the effects of spectacular waterfalls in Asia in 1997 and the United States in 2000 and the CAC40 has thus lost $15 \%$ in four months.

We call these interdependencies and transmissions of crises from one country to the other of contagion.

\section{Research Methodology and the Presentation of the Results}

According to the literature, the contagion is present as the significant change in the mechanisms of spread of shocks caused by a country or group of countries. This change is in fact a synonym for generation of new channels of propagation, which causes the presence of contagion within the meaning of Forbes and Rigobon (2001). In the recent empirical work, this change is identified via the non-linearity which figure in the interdependence between the financial markets (Favero and Giavazzi, 2002; Waïlti 2003; Bonfiglioli and Favero, 2005).

To do this, we proceed via two tests. The first is to test the significant increase of the correlations between the quiet period

and the period of crisis. However that the second test concerns the cointegration which is developed by Johansen (1991.1995), from this test we will try to know the degree of integration of markets fellow in period of the crisis of subprime.

Our study therefore is based on the determination of the behavior of stock markets during the period of the crisis of subprime via the phenomenon of integration and the contagion, the variable used in this study is none other than the stock index. To this effect, the data that will serve as the basis for the analysis are of stock exchange data on daily and which are extracts from the Web site data stream.

The databases used in this study are daily data of the prices of stock indices of 5 developed markets and 5 emerging markets. They have been extracted from the base of the site "Yahoo Finance and economists." These indices cover the period from January 2007 until June 2014, which gives us 2000 Comments by market. The sample is as follows:

Developed markets:

- North-America: United States,

- Europe: France, Germany, United Kingdom,

- Asia: Japan,

As well, the question of contagion of financial markets is of capital importance. In effect, it has an interest both practical and theoretical. In a comprehensive way, our work will allow a better understanding of the financial market in the face of the diversification. The objective of this research is to analyze the degree contagion between the financial markets during the crisis of subprime. In this part we will first try to measure the degree of contagion between the financial markets through the correlation between markets and statistics descriptive. Then, we will analyze the contagion in the developed markets through the test of cointegration and causality.

\subsection{Descriptive Analysis of the Sample}

The table (1) and (2) below contain the descriptive statistics of the yields of the stock indices of developed and emerging markets selected in the sample which decomposes 1696 observations.

$$
\text { Performance }_{\mathrm{t}}=\ln \left(\mathrm{P}_{\mathrm{t}+1} / \mathrm{p}_{\mathrm{t}}\right)
$$

It will be seen from the table (1) that for the developed markets, average yields the highest are attributed to the bourse of Germany $0,0305 \%$ and France with $0.0214 \%$ while the most low is registered in the United States; either $0,0012 \%$. The maximum yield varies from $7.18 \%$ in Germany to $6.31 \%$ in the United Kingdom while the minimum performance fluctuates between $-6,95 \%$ in Germany and $-5,32 \%$ in the USA.

In term of risk, the Bourse of ETAS United has the least risk; either, $11.331 \%$ while that the higher is marked on the stock exchange of the Germany with a standard deviation of $16.124 \%$. 
Table 1. Descriptive Statistics of the Yields*of stock indices developed markets.

\begin{tabular}{llllll}
\hline & United States & U. k. & FRANCE & Germany & Japan \\
\hline Average & $-0,000012$ & 0,000191 & 0,000214 & 0,000305 & 0,0000631 \\
Median & 0,0000325 & 0,000245 & 0,000546 & 0,000875 & 0.000000 \\
Maximum & 0,056104 & 0,063160 & 0,059568 & 0,071889 & 0,057712 \\
Minimum & $-0,053244$ & $-0,052735$ & $-0,063355$ & $-0,069557$ & $-0,071582$ \\
Standard deviation & 0,011331 & 0,011083 & 0,013302 & 0,016124 & 0,013427 \\
Skewness & 0,14256 & 1,79564 & $-0,185462$ & $-0,198645$ & $-0,145896$ \\
Kurtosis & 5,212545 & 5,524125 & 5,215423 & 5,65482 & 4,62538 \\
Jarque-Bera & 630,4731 & 577,2920 & 430,1781 & 462,7047 & 201,3729 \\
Likelihood & 0.000000 & 0.000000 & 0.000000 & 0.000000 & 0.000000 \\
number of observation & 2000 & 2000 & 2000 & 2000 & 2000 \\
\hline
\end{tabular}

*yields are calculated by the natural logarithm of the difference between the prices of stock indices:

Table 2. Descriptive Statistics of the yields of the stock indices of Emerging Markets.

\begin{tabular}{|c|c|c|c|c|c|}
\hline & Argentina & China & Egypt & Malaysia & Mexico \\
\hline Average & 0,000446 & 0,000245 & 0,001150 & 0,000413 & 0,000731 \\
\hline Median & 0,000254 & 0,000524 & 0.000000 & 0.000000 & 0,001215 \\
\hline Maximum & 0,17251 & 0,069609 & 0,081652 & 0,049610 & 0,073002 \\
\hline Minimum & $-0,30214$ & $-0,099276$ & $-0,090046$ & $-0,032501$ & $-0,075113$ \\
\hline Standard deviation & 0,025265 & 0,014521 & 0,01568 & 0,008215 & 0,013265 \\
\hline Skewness & $-1,21256$ & $-0,25426$ & 0,052642 & $-0,52154$ & $-0,15148$ \\
\hline Kurtosis & 29,42564 & 4,32165 & 6,51245 & 8,34125 & 6,52132 \\
\hline Likelihood & 0.000000 & 0.000000 & 0.000000 & 0.000000 & 0.000000 \\
\hline number of observation & 2000 & 2000 & 2000 & 2000 & 2000 \\
\hline
\end{tabular}

With regard to the emerging markets (Table 2), Egypt has the average yield the highest; either $0.115 \%$, while that the lowest corresponds to the bourse of China $0,0245 \%$. The maximum yield varies from $17,251 \%$ in Argentina to $8,16 \%$ in Egypt while the minimum yield varies from $-30,214 \%$ to Argentina to $3.25 \%$ in Malaysia.

In term of risk, the stock exchange of Malaysia has the least risk; either, $0,8215 \%$ while that the higher is marked on the stock exchange of the Argentina with a standard deviation of $2,252 \%$.

The values of the statistics of kurtosis indicate that the series have a thick character. The coefficients of skewness indicate that the distribution is skewed to the left and reject the normal distribution for the majority of the series. Therefore, the assumption of normality is not checked and the test Jarque-Bera confirms this result and rejects significantly the normal distribution of the yields of the stock indices for all markets forming the sample.

\subsection{Study of Correlations of Yields}

The study of the correlation coefficients between the yields of stock market indices is the simplest technique to explain the integration of financial markets. Indeed, more this coefficient is close to the unit, the more the hypothesis of integration is accepted given that such a result means that the markets incorporate the information in the same way. The tables (3) and (4) present the correlation coefficients between the yields of stock indices to the markets of developed countries.

Table 3. The correlations between returns * of stock indices developed markets.

\begin{tabular}{llllll}
\hline & United States & Royan United & Germany & France & Japan \\
\hline United States & 1.000000 & 0.41235 & 0.554256 & 0.52356 & 0.10465 \\
United Kingdom & & 1.000000 & 0.70253 & 0.851256 & 0.18695 \\
Germany & & 1.000000 & 0.895212 & 0.16523 \\
France & & & 1.000000 & 0.125645 \\
Japan & & & & 1.000000 \\
\hline
\end{tabular}

*yields are calculated by the natural logarithm in the difference of stock indices: Performance ${ }_{t}=\ln \left(\mathrm{P}_{t+1} / \mathrm{p}_{\mathrm{t}}\right)$

The developed markets are strongly correlated. The highest correlation is $89,52 \%$ between France and Germany, followed by the couple France; Royan united with a correlation coefficient of $85,125 \%$, we note also a high correlation coefficient of the order of $70,253 \%$ between Royan United and Germany. This is explained by the fact that these countries belong to the same economic bloc. The Correlation The most low is of $10,465 \%$ between the United States and Japan.

The correlation coefficients between the yields of stock indices of emerging markets as the table shows (4) are low and times negative. These coefficients vary from $-1,568 \%$ between the Egyptian market and Argentina to 30,265\% between Malaysia and China. This result confirms the independence of these markets. 
Table 4. The correlations of returns between the stock indices of Emerging Markets.

\begin{tabular}{llllll}
\hline & Argentina & China & Egypt & Malaysia & Mexico \\
\hline Argentina & 1.000000 & 0.095689 & -0.015685 & 0.032683 & 0.275533 \\
China & & 1.000000 & 0.06548 & 0.30265 & 0.25268 \\
Egypt & & 1.000000 & 0.06586 & 0.019854 \\
Malaysia & & & 1.000000 & 0.11569 \\
Mexico & & & & 1.000000 \\
\hline
\end{tabular}

Table 5. The correlations of returns between the stock indices of developed and emerging markets.

\begin{tabular}{llllll}
\hline & Argentina & China & Malaysia & Mexico & Egypt \\
\hline United States & 0.184569 & 0.12568 & 0.0112568 & 0.58965 & -0.028965 \\
United Kingdom & 0.125648 & 0.202458 & 0.112356 & 0.43569 & -0.007063 \\
France & 0.198311 & 0.28464 & 0.101246 & 0.474218 & -0.017586 \\
Germany & 0.171458 & 0.21263 & 0.07338 & 0.55126 & -0.018568 \\
Japan & 0.085469 & 0.44589 & 0.23569 & 0.15256 & 0.07589 \\
\hline
\end{tabular}

The correlation coefficients between the yields of developed and emerging markets are very low and sometimes negative. This shows that the emerging markets are very weakly correlated with the developed markets as shown in the table (5). The level of correlation is highest recorded between the United States and Mexico, either $58.965 \%$ followed by the market of Germany and Mexico $51,259 \%$. However, the correlation coefficient the more low is of $-2.89 \%$ between the United States and Egypt. Thus, as compared to the developed markets that present a strong correlation between them involving as well their strong integration, the emerging markets have a low dependency relationship both between themselves and with the developed markets.

This independence between the developed and emerging markets implies the presence of contagion.

Our results prove that the developed markets are integrated between them while the emerging markets are segmented as well as between themselves and with the developed markets. These findings are consistent with the majority of the studies conducted on the theme of the integration and the contagion of financial markets such as that of Gilmore and McManus (2002) and Bekaert, Harvey and Ng (2003).

\subsection{Study of the Cointegration}

\subsubsection{Unit Root Test of the Series: ADF Test}

$A$. Unit Root Test of the series: emerging countries

Stationarity of the series in level

We test here the assumptions:

$\mathrm{H}_{0}$ : the series in level is non-stationary

$\mathrm{H}_{1}$ : the series in level is stationary

The application of the test of unit root test series in level allows us to draw the following table

Table 6. Stationarity in level: emerging countries.

\begin{tabular}{l|lllll}
\hline \multicolumn{2}{l}{ Stationarity in level: emerging countries } & & & \\
\hline Years & France & Germany & Japan & U. k. & USA \\
\hline \multirow{2}{*}{ Model } & Without Constance or & Without Constance & Without consistency & Without trend or & Without trend or \\
& trend & Or trend & and with trend & Constance & Constance \\
T. statistics & 1.476123 & 1.609054 & 0.720213 & 2.136614 & 2.633606 \\
& -2.5036525 & -2.5426350 & -3.432658 & -2.5698365 & -2.242568 \\
Critical values (thresholds & -1.958656 & -1.9584652 & -2.122456 & -1.954256 & -1.965384 \\
$1 \%, 5 \%$ and $10 \%)$ & -1.542633 & -1.425369 & -1.425689 & -1.425368 & -1.412564 \\
& 0,9756 & 0,9587 & 0.99452 & 0,99524 & 0.99845 \\
Likelihood & No & No & No & No & No \\
Stationarity & & &
\end{tabular}

The table (6) relative to the ADF test within the emerging area highlights a value of $\mathrm{t}$ statistics lower in absolute value to the critical values for the three thresholds $(1 \%, 5 \%$ and $10 \%)$. The equity indices of these countries are therefore non-stationary. Accordingly to this non stationarity, we turn the test level to the first differentiation (variation of the index).

Stationarity of differentiated series

We test here the hypothesis:

$\mathrm{H}_{0}$ : the series in first difference is non-stationary

$\mathrm{H}_{1}$ : the series in first difference is stationary

The application of the test of unit root test of differentiated series allows us to draw the following table: 
Table 7. Stationarity of differentiated series: emerging countries.

\begin{tabular}{llllll}
\hline \multicolumn{2}{l}{ Stationarity of differentiated series: emerging countries } & & & \\
\hline Years & Argentina & China & Egypt. & Malaysia & Mexico City \\
\hline \multirow{2}{*}{ Model } & Without Constance or & Without Constance & Without consistency & Without trend or & Without trend or \\
& trend & Or trend & and with trend & Constance & Constance \\
T. statistics & -40.53294 & -37.99137 & -19.83045 & -32.91454 & -36.263682 \\
Critical values (thresholds & -2.526485 & -2.546856 & -3.758453 & -2.548546 & 2.895762 \\
$1 \%, 5 \%$ and 10\%) & -1.95685 & -1.542628 & -2.846958 & -1.968545 & -1.458765 \\
& -1.75869 & -1.425698 & -2.597822 & -1.759856 & -1.756849 \\
Likelihood & 0.0000 & 0.0000 & 0.0000 & 0.0000 & 0.0000 \\
Stationarity & Yes & Yes & Yes & Yes & Yes \\
\hline
\end{tabular}

The table (7) relative to the ADF test within the emerging area indicates to us that the t statistics of the country are largely higher in absolute value to the different critical thresholds already listed. We conclude that the indices relating to these countries are integrated of order (1) or I (1).

B. Unit root test of the series: developed countries

Stationarity of the series in level

We test here the assumptions:

$\mathrm{H}_{0}$ : the series in level is non-stationary

$\mathrm{H}_{1}$ : the series in level is stationary

The application of the test of unit root test series in level allows us to draw the following table:

Table 8. Stationarity in level: developed countries.

\begin{tabular}{|c|c|c|c|c|c|}
\hline \multicolumn{6}{|c|}{ Stationarity in level: developed countries } \\
\hline Years & France & Germany & Japan & U. $k$. & USA \\
\hline Model & $\begin{array}{l}\text { Without Constance or } \\
\text { trend }\end{array}$ & $\begin{array}{l}\text { Without Constance } \\
\text { Or trend }\end{array}$ & $\begin{array}{l}\text { Without Constance } \\
\text { or trend }\end{array}$ & $\begin{array}{l}\text { Without trend and } \\
\text { with Constance }\end{array}$ & $\begin{array}{l}\text { Without trend and } \\
\text { with Constance }\end{array}$ \\
\hline T. statistics & 0.954604 & 0.980872 & 0.083750 & 0.154461 & -1.7536743 \\
\hline \multirow{3}{*}{$\begin{array}{l}\text { Critical values (thresholds } \\
1 \%, 5 \% \text { and } 10 \%)\end{array}$} & -2.566326 & -2.566574 & -2.566327 & -3.434004 & -3.434004 \\
\hline & -1.941010 & -1.941010 & -1.1941010 & -2.863041 & -2.863041 \\
\hline & -1.616574 & -1.616574 & -1.616574 & -2.567616 & -2.567616 \\
\hline Likelihood & 0.9102 & 0.9141 & 0.7091 & 0.9696 & 0.4009 \\
\hline Stationarity & No & No & No & No & No \\
\hline
\end{tabular}

The table (8) relative to the ADF test within the developed zone highlights a value of $t$ statistics lower in absolute value to the critical values for the three thresholds $(1 \%, 5 \%$ and $10 \%)$. The equity indices of these countries are therefore nonstationary. Accordingly to this non stationarity, we turn the test level to the first differentiation (variation of the index).

Stationarity of differentiated series

We test here the hypothesis:

$\mathrm{H}_{0}$ : the series in first difference is non-stationary

$\mathrm{H}_{1}$ : the series in first difference is stationary

The application of the test of unit root test allows us to draw up this table:

Table 9. Stationarity of differentiated series: developed countries.

\begin{tabular}{llllll}
\hline \multicolumn{6}{l}{ Stationarity of differentiated series: developed countries } \\
\hline Years & France & Germany & Japan & U. k. & USA \\
\hline Model & Without Constance or & Without Constance & Without Constance or & Without trend and & Without trend and \\
& trend & Or trend & trend & with Constance & with Constance \\
T. statistics & -40.91449 & 40.84984 & -40.80654 & -42.20899 & -42.149421 \\
Critical values (thresholds & -2.566327 & -2.566574 & -2.566327 & -3.434004 & -3.434004 \\
$1 \%, 5 \%$ and $10 \%)$ & -1.941010 & -1.941010 & -1.1941010 & -2.863041 & -2.863041 \\
& -1.616574 & -1.616574 & -1.616574 & -2.567616 & -2.567616 \\
Likelihood & 0.0000 & 0.0000 & 0.0000 & 0.0000 & 0.0000 \\
Stationarity & Yes & Yes & Yes & Yes & Yes \\
\hline
\end{tabular}

The table (9) relative to the ADF test within the developed zone indicates to us that the $t$ statistics of the country are largely higher in absolute value to the different critical thresholds already listed. We conclude that the indices relating to these countries are integrated of order (1) or I (1).

In summary, the various indices have the same order of integration, in effect, according to the previous tests, we have clarified that these series are integrated of order 1, or I (1), 
To estimate the cointegration of the series on the long term, we can proceed to a test of cointegration multi varied, or even called test of Johansen (1988) and/ or a test of cointegration bi varied from Engle and Granger (1987); and on the short term, we will proceed to the test of the VECM (Model of vector to correction of error).

\subsubsection{The Determination of the Number of Delay}

a The determination of the number of delay: the developed markets

For the whole of the developed markets, the criteria AIC and SC Are minimum for a $\mathrm{P}=3$ and therefore the VAR model to retain is of order 3 .

Table 10. Determination of the number of delay $(P)$ : Developed Countries.

\begin{tabular}{lllll}
\hline Number of delay & & & & \\
\hline The criteria & VAR(1) & VAR(2) & VAR(3) & VAR(4) \\
\hline Akaike & 7.685745 & 7.5320365 & 7.536458 & 7.548462 \\
Schwarz & 7.698754 & 7.5841259 & 7.589452 & 7.598640 \\
\hline
\end{tabular}

$b$ The determination of the number of delay: the Emerging Markets

For the whole of the emerging markets, the criteria AIC and SC Are minimum for a $\mathrm{P}=2$ and therefore the VAR model to retain is of order 2 .

Table 11. Determination of the number of delay $(P)$ : emerging countries.

\begin{tabular}{llllll}
\hline \multicolumn{4}{l}{ Number of delay: emerging countries } \\
\hline The criteria & VAR(1) & VAR(2) & VAR(3) & VAR(4) \\
\hline Akaike & 1.024516 & 0.901258 & 0.901125 & 0.912456 \\
Schwarz & 1.045869 & 0.9125468 & 0.9012580 & 0.9869586 \\
\hline
\end{tabular}

The determination of the number of delay $(\mathrm{P})$ of the model Autoregressive Vector VAR (P) is an important step in our empirical study on the integration of markets. For the case of developed markets, it was a VAR of order 3 since the criteria AIC (Akaike information criterion) and SC (Schwarz criterion) are minimum for a $\mathrm{P}=3$ (Table 10). With regard to the emerging countries it was a VAR of order 2 since the criteria are nominal for a $\mathrm{P}=2$, (Table 11$)$.

\subsubsection{Test for Cointegration}

The assumptions of the test are:

$\mathrm{H}_{0}$ : the presence of at least one cointegrating relationship

$\mathrm{H}_{1}$ : absence of cointegration relationship between series

c Test of cointegration: the developed markets

The application of the test of Johansen allows us to draw the table below:

Table 12. Test of co-integration multi-variety of Johansen: Developed Countries.

\begin{tabular}{llll}
\hline No. of cointegrating relationship & Clean value & Trace statistics & Critical value (5\%) \\
\hline No* & 0.031470 & 127.1427 & 88.80380 \\
At most $1 *$ & 0.015889 & 73.00827 & 63.87610 \\
At the most 2* & 0.012465 & 45.89230 & 0.024528 \\
At most 3 & 0.009623 & 24.65830 & 25.87211 \\
At most 4 & 0.004883 & 8.287718 & 12.51798 \\
\hline
\end{tabular}

*indicates that we must reject $\mathrm{H}_{1}$ and go to the second iteration.

The test of multivariate cointegration of Johansen between the developed markets shows the existence of three cointegrating relationships. These results indicate that these markets are integrated between them on the long term. Indeed, the presence of this cointegrating relationship between these markets explains their convergences toward a certain level of stable balance of the long-term. Subsequently, the presence of this cointegrating relationship therefore translated the contagion between these markets.

The use of the tests for cointegration bivariate notes the existence of nine cointegrating relationships, it is of the France-Germany couples (Table 13), France-Japan (Table 14), France-Royaume UNI (Table 15), France and the USA
(Table 16), Germany-Japon (Table 17), Germany-Royaume Uni (Table 18), Germany-USA (Table 19), Japon-Royaume UNI (Table 20) and USA-United Kingdom (Table 21). These results are evident due to strong economic links between these countries.

In other words, we can say from the results of cointegration tests that the overall evolution of indices of these markets appears to parallel the period, which leads us to talk about mutual interdependence within these groups, we think that the crisis in 2007 has affected the further integration.

This means that the international diversification is not beneficial on these markets.

Table 13. Test of bivariate cointegration of Johansen: France-Germany.

\begin{tabular}{llll}
\hline No. of cointegrating relationship & Clean value & Trace statistics & Critical value (5\%) \\
\hline No* & 0.212863 & 32.45365 & 25.87211 \\
At most a & 0.005087 & 8.634956 & 12.51798 \\
\hline
\end{tabular}

*There is no cointegrating relationship 
Table 14. Test of bivariate cointegration of Johansen: france-Japan

\begin{tabular}{llll}
\hline No. of cointegrating relationship & Clean value & Trace statistics & Critical value (5\%) \\
\hline No* & 0.010922 & 27.22682 & 25.87211 \\
At most a & 0.005087 & 8.634956 & 12.51798 \\
\hline
\end{tabular}

*There is no cointegrating relationship

Table 15. Test of bivariate cointegration of Johansen: France-Royaume uni.

\begin{tabular}{llll}
\hline No. of cointegrating relationship & Clean value & Trace statistics & Critical value (5\%) \\
\hline No* & 0.024000 & 51.14509 & 25.87211 \\
At most a & 0.005899 & 10.01669 & 12.51798 \\
\hline
\end{tabular}

*There is no cointegrating relationship

Table 16. Test of bivariate cointegration of Johansen: France-USA.

\begin{tabular}{llll}
\hline No. of cointegrating relationship & Clean value & Trace statistics & Critical value (5\%) \\
\hline No* & 0.008955 & 26.81028 & 25.87211 \\
At most a & 0.006817 & 11.58072 & 12.51798 \\
\hline
\end{tabular}

*There is no cointegrating relationship

Table 17. Test of bivariate cointegration of Johansen: Germany-Japon.

\begin{tabular}{llll}
\hline No. of cointegrating relationship & Clean value & Trace statistics & Critical value (5\%) \\
\hline No* & 0.011058 & 25.87485 & 25.87211 \\
At most a & 0.004156 & 7.050194 & 12.51798 \\
\hline
\end{tabular}

*There is no cointegrating relationship

Table 18. Test of bivariate cointegration of Johansen: Germany-Royaume uni.

\begin{tabular}{llll}
\hline No. of cointegrating relationship & Clean value & Trace statistics & Critical value (5\%) \\
\hline No* & 0.012681 & 30.91364 & 25.87211 \\
At most a & 0.005482 & 9.306623 & 12.51798 \\
\hline
\end{tabular}

*There is no cointegrating relationship

Table 19. Test of bivariate cointegration of Johansen: Germany-USA.

\begin{tabular}{llll}
\hline No. of cointegrating relationship & Clean value & Trace statistics & Critical value (5\%) \\
\hline No* & 0.009924 & 27.98490 & 25.87211 \\
At most a & 0.006535 & 11.09955 & 12.51798 \\
\hline
\end{tabular}

*There is no cointegrating relationship

Table 20. Test of bivariate cointegration of Johansen: Japon-Royaume uni.

\begin{tabular}{llll}
\hline No. of cointegrating relationship & Clean value & Trace statistics & Critical value (5\%) \\
\hline No* & 0.010857 & 26.84570 & 25.87211 \\
At most a & 0.004928 & 8.363618 & 12.51798 \\
\hline
\end{tabular}

*There is no cointegrating relationship

Table 21. Test of bivariate cointegration of Johansen: USA-United Kingdom.

\begin{tabular}{llll}
\hline No. of cointegrating relationship & Clean value & Trace statistics & Critical value (5\%) \\
\hline No* & 0.011567 & 29.97548 & 25.87211 \\
At most a & 0.006052 & 10.27799 & 12.51798 \\
\hline
\end{tabular}

*There is no cointegrating relationship

B. The test for cointegration: Emerging Markets

Table 22. Test of co-integration multi-variety of Johansen: Emerging Countries.

\begin{tabular}{llll}
\hline No. of cointegrating relationship & Clean value & Trace statistics & Critical value (5\%) \\
No* & 0.024664 & 96.30380 & 88.80380 \\
At most 1 & 0.014183 & 53.99990 & 93.87610 \\
More than 2 & 0.010389 & 29.80261 & 42.91525 \\
At most 3 & 0.005457 & 12.11128 & 25.87211 \\
At most 4 & 0.001676 & 2.841974 & 12.51798 \\
\hline
\end{tabular}


The test of multivariate cointegration of Johansen between emerging markets shows the existence of a single cointegrating relationship.

In effect, in order to determine which of these markets are cointegrated, we will proceed to test bivariate Johansen. We find from the tables below, that the couple Chine-Malaisie cointegrated is within the meaning of Engele and Granger. The other couples are not cointegrated.

Table 23. Test of bivariate cointegration of Johansen: Argentina-china.

\begin{tabular}{llll}
\hline No. of cointegrating relationship & Clean value & Trace statistics & Critical value (5\%) \\
\hline No* & 0.008398 & 23.09445 & 25.87211 \\
At most a & 0.005186 & 8.808585 & 12.51798 \\
\hline
\end{tabular}

*There is no cointegrating relationship

Table 24. Test of bivariate cointegration of Johansen: Argentina-Egypt.

\begin{tabular}{llll}
\hline No. of cointegrating relationship & Clean value & Trace statistics & Critical value (5\%) \\
\hline No* & 0.007895 & 19.15899 & 25.87211 \\
At most a & 0.003378 & 5.732449 & 12.51798 \\
\hline
\end{tabular}

*There is no cointegrating relationship

Table 25. Test of bivariate cointegration of Johansen: Argentina-Malaysia.

\begin{tabular}{llll}
\hline No. of cointegrating relationship & Clean value & Trace statistics & Critical value (5\%) \\
\hline No* & 0.0078128 & 16.84962 & 25.87211 \\
At most a & 0.002789 & 4.731368 & 12.51798 \\
\hline
\end{tabular}

*There is no cointegrating relationship

Table 26. Test of bivariate cointegration of Johansen: Argentina-mexico.

\begin{tabular}{llll}
\hline No. of cointegrating relationship & Clean value & Trace statistics & Critical value (5\%) \\
\hline No* & 0.006138 & 18.21988 & 25.87211 \\
At most a & 0.004588 & 7.789455 & 12.51798 \\
\hline
\end{tabular}

*There is no cointegrating relationship

Table 27. Test of bivariate cointegration of Johansen: China-Egypt.

\begin{tabular}{llll}
\hline No. of cointegrating relationship & Clean value & Trace statistics & Critical value (5\%) \\
\hline No* & 0.007944 & 16.48281 & 25.87211 \\
At most a & 0.001753 & 2.972685 & 12.51798 \\
\hline
\end{tabular}

*There is no cointegrating relationship

Table 28. Test of bivariate cointegration of Johansen: China-Malaysia.

\begin{tabular}{llll}
\hline No. of cointegrating relationship & Clean value & Trace statistics & Critical value (5\%) \\
\hline No* & 0.009959 & 27.41162 & 25.87211 \\
At most a & 0.006153 & 10.45581 & 12.51798 \\
\hline
\end{tabular}

*There is no cointegrating relationship

Table 29. Test of bivariate cointegration of Johansen: China-mexico.

\begin{tabular}{llll}
\hline No. of cointegrating relationship & Clean value & Trace statistics & Critical value (5\%) \\
\hline No* $^{*}$ & 0.007579 & 18.82713 & 25.87211 \\
At most a & 0.003500 & 5.940223 & 12.51798 \\
\hline
\end{tabular}

*There is no cointegrating relationship

Table 30. Test of bivariate cointegration of Johansen: Egypt.-Malaysia.

\begin{tabular}{llll}
\hline No. of cointegrating relationship & Clean value & Trace statistics & Critical value (5\%) \\
\hline No* & 0.005023 & 10.86441 & 25.87211 \\
At most a & 0.001377 & 2.333421 & 12.51798 \\
\hline
\end{tabular}

*There is no cointegrating relationship 
Table 31. Test of bivariate cointegration of Johansen: Egypt.-mexico.

\begin{tabular}{llll}
\hline No. of cointegrating relationship & Clean value & Trace statistics & Critical value (5\%) \\
\hline No* & 0.005274 & 15.02578 & 25.87211 \\
At most a & 0.003576 & 6.067973 & 12.51798 \\
\hline
\end{tabular}

*There is no cointegrating relationship

Table 32. Test of bivariate cointegration of Johansen: Malaysia-mexico.

\begin{tabular}{llll}
\hline No. of cointegrating relationship & Clean value & Trace statistics & Critical value (5\%) \\
\hline No* & 0.006222 & 15.65424 & 25.87211 \\
At most a & 0.002995 & 5.080587 & 12.51798 \\
\hline
\end{tabular}

*There is no cointegrating relationship

We note that the hypothesis of cointegration is not verified for all couples of emerging markets. This can be explained by the absence of globalization to the internal market that form the groups which means that these markets are still segmented, or they are independent of the financial turmoil that affected several markets during this period. In other words, these markets do not respond strongly to financial shocks and are far from being affected by contagion during financial crises that occurred during this period. These markets therefore resist any increases or decreases that take place on other financial centers. Nevertheless, the absence of cointegration relationship does not necessarily mean absence of contagion but it simply means absence of globalization, for better resistance to decline relative to other markets and also different sensitivities of the various markets to shocks.

To study the movements of the short-term it has had recourse to the model VECM (vector error correction model). According to the results obtained in the table ... We note that the coefficients of adjustments to the balance are not negative which implies that the VECM is not valid and therefore these markets are not integrated in the short term.

The application of the model VECM allows us to draw the table below:

Table 33. Model VECM: Emerging Countries.

\begin{tabular}{llllll}
\hline VECM model: Emerging Countries & Argentina & China & Egypt. & Malaysia & Mexico City \\
\hline Conditions & $-0.020314 *$ & $6.61 \mathrm{E}-05$ & 0.001341 & $-0.001039^{*}$ & $-0.00086^{*}$ \\
\hline Significance & negative & Positive & Positive & The negative & negative \\
Return Force $(<0)$ & & &
\end{tabular}

*The coefficient is significant at the $5 \%$ threshold

C. Test of cointegration: developed markets-developed markets

Table 34. Test of co-integration multi-variety of Johansen: Emerging Countries-developed countries.

\begin{tabular}{ll|ll}
\hline No. of cointegrating relationship & Clean value & Trace statistics & Critical value (5\%) \\
\hline No* & 0.048941 & 324.9026 & 273.1889 \\
At most $1 *$ & 0.037650 & 239.8761 & 228.2979 \\
More than 2 & 0.026941 & 92.08150 & 187.4701 \\
At most 3 & 0.018810 & 59.51393 & 117.7082 \\
At most 4 & 0.011328 & 59.51393 & 88.80380 \\
More than 5 & 0.011328 & 40.91461 & 88.80380 \\
More than 6 & 0.008792 & 25.65500 & 93.87610 \\
More than 7 & 0.007656 & 12.63499 & 42.91525 \\
Over 8 & 0.005001 & 4.141812 & 25.87211 \\
The more 9 & 0.002442 & 12.51798 \\
\hline
\end{tabular}

The above table (Table 34) has cointegration between emerging and developed markets; it shows that there is a cointegration relationship. The presence of the relationship between markets may indicate the existence of permanent channels in the transmission of shocks between these countries, in other words, this is evidence of contagion.

Furthermore, the existence of co-integrating relationship emerging markets with developed markets shows a significant interdependence between these markets and demonstrates the importance of reforms adopted by the emerging markets, as part of a well planned process of financial liberalization, to follow global trends and attract more and more of foreign capital in various forms (FDI investment portfolios, trade, free trade agreements, international bank credit,......).

To check the cointegration of the short term, it has had recourse to the test of bivariate cointegration within the area of the developed countries and emerging economies (Tables 35 and 36) who has indicated two cointegrating relationships. 
Table 35. Test of bivariate cointegration of Johansen: Argentina.-France.

\begin{tabular}{llll}
\hline No. of cointegrating relationship & Clean value & Trace statistics & Critical value (5\%) \\
\hline No & 0.008471 & 26.20316 & 25.87211 \\
At most a & 0.006937 & 11.79294 & 12.51798 \\
\hline
\end{tabular}

Table 36. Test of bivariate cointegration of Johansen: Argentina.-Japan.

\begin{tabular}{llll}
\hline No. of cointegrating relationship & Clean value & Trace statistics & Critical value (5\%) \\
\hline No & 0.012123 & 25.53624 & 25.87211 \\
At most a & 0.004628 & 7.874554 & 12.51798 \\
\hline
\end{tabular}

On the other hand the analysis of cointegration between the other torques of emerging markets and developed shows the non-existence of no cointegration relationship which favors the segmentation.

\subsection{The Causality: Evidence of Contagion}

The idea of causation in economy is an old idea, the fruit of economists and financial that found in the econometric techniques a means to be established and tested. The direction of the causality economic opportunities is a critical element to develop an economic policy or to make forecasts.

The assumptions of the test are:

$\mathrm{H}^{0}$ : the " $\mathrm{x}$ " index does not cause the other Index " $y$ "

$\mathrm{H}^{1}$ : the" $\mathrm{x}$ " index because the other Index " $\mathrm{y}$ "

\subsubsection{The Causality Between Emerging Countries}

The application of the test of causation to the series of stock market indices of emerging markets allows us to draw the table below:

Table 37. Causality of emerging countries.

\begin{tabular}{|c|c|c|c|}
\hline Meaning of causal relationship & & Likelihood & Decision of causation \\
\hline China & Argentina & 0.1526 & NO \\
\hline Argentina & China & 0.0621 & NO \\
\hline Egypt. & Argentina & 0.0452 & NO \\
\hline Argentina & Egypt. & 2.7E-06 & Yes \\
\hline Malaysia & Argentina & 0.08685 & NO \\
\hline Argentina & Malaysia & $1.4 \mathrm{E}-10$ & Yes \\
\hline Mexico City & Argentina & 0.01263 & Yes \\
\hline Egypt. & China & 0.0498 & NO \\
\hline China & Egypt. & 0.1638 & NO \\
\hline Malaysia & China & 0.78952 & NO \\
\hline China & Malaysia & 0.00856 & Yes \\
\hline Mexico City & China & $7.5 \mathrm{E}-39$ & Yes \\
\hline China & Mexico City & 0.08963 & $\mathrm{NO}$ \\
\hline Malaysia & Egypt. & $3.6 \mathrm{E}-05$ & Yes \\
\hline Mexico City & Egypt. & $3.4 \mathrm{E}-14$ & Yes \\
\hline Egypt & Mexico City & 0.23265 & NO \\
\hline Mexico City & Malaysia & 0.05986 & $\mathrm{NO}$ \\
\hline Malaysia & Mexico City & 0.19758 & NO \\
\hline
\end{tabular}

The determination of the test of causality in the Granger sense has shown that couples of the markets - China, MalaysiaMexico, China present bi-directional relationships on the long term therefore any shock will impact on each country.

For couples Egypt-Argentina, Malaysia-Argentina, Mexico-Argentina, Mexico-Egypt, Mexico-China, MalaysiaChina, Argentina-Mexico. We note of after the probabilities related to the statistics of file to threshold 5\% that there are relations of causal unidirectional.

As well, the shocks that affect a given market will influence very significantly the movements of the other market. In contrast, a shock on the latter market is not transmitted on the first market.

Several factors explain these results such as the Asian crisis, the movements and the links between these countries and the upheavals of the world financial stage.

On the other hand our study shows the existence of relations of non causality between couples- Mexico Malaysia- China Argentine-Argentine Mexico. This result reflects the segmentation between these markets which constitutes a favorable environment for benefit of the gains of diversification.

\subsubsection{The Causality Between the Developed Countries}

The assumptions of the test are:

$\mathrm{H}^{0}$ : the $\mathrm{x}$ index does not cause the other Index $\mathrm{y}$

$\mathrm{H}^{1}$ : the $\mathrm{x}$ index because the other Index $\mathrm{y}$

The application of the test of causation to the series of stock indices developed markets allows us to draw the table below 
Table 38. Causality of developed Countries

\begin{tabular}{llll}
\hline Meaning of causal relationship & & Likelihood & Decision of causation \\
\hline Germany & France & $6.1 \mathrm{E}-09$ & Yes \\
France & Germany & 0.00524 & Yes \\
Japan & France & 0.50120 & NO \\
France & Japan & $1.4 \mathrm{E}-38$ & Yes \\
Kingdom & United France & 0.11245 & NO \\
France & U. K. & 0.01326 & Yes \\
USA & France & $4.6 \mathrm{E}-37$ & Yes \\
France & USA & 0.00463 & Yes \\
Japan & Germany & 0.81235 & NO \\
Germany & Japan & $1.2 \mathrm{E}-41$ & Yes \\
U. k. & Germany & 0.002425 & Yes \\
Germany & U. K. & $2.5 \mathrm{E}-07$ & Yes \\
USA & Germany & $4.2 \mathrm{E}-15$ & Yes \\
Germany & USA & 0.011123 & Yes \\
U. k. & Japan & $4.2 \mathrm{E}-27$ & Yes \\
Japan & U. K. & 0.88562 & NO \\
USA & Japan & $2.5 \mathrm{E}-42$ & Yes \\
Japan & USA & 0.06253 & NO \\
USA & U. K. & $3.4 \mathrm{E}-34$ & Yes \\
U. k. & USA & NO \\
\hline
\end{tabular}

The determination of the test of causality in the Granger sense has shown that couples of markets present- Germany France - USA France - United Kingdom Germany - USA Germany of bidirectional relations on the long term therefore any shock will impact on each country. Also, the use of the Granger causality test allows us to identify the direction of causality between these markets cointegrated. The existence of relations of causality is interpreted as a sign of contagion.

According to the table (38) as well as the annex(10), we find for couples of markets -Japan France- Royan united France - Japan Germany - United Kingdom - Japan-USA United Kingdom -that it' exists of causal relationships of unidirectional torque of market.

For example for the Torque Japan- USA a shock on the American market will influence on the Japanese market. On the other hand a shock on the Japanese market does not affect the U. S. market. Therefore the test of causality well confirms the relationship of the short term.

\section{Conclusion}

The contagion during the crisis now remains a subject of great debate on the academic plan. Several works have been presented, the objective of which is to search for the causes and the failures at the origin of this phenomenon.

Following the occurrence of the crisis of "subprime" which took birth in the United States in July 2007, the goal of this article was to analyze the behavior of stock markets in Europe during this crisis and to show the impact of the crisis of subprime on the stock markets while interesting on the contagion.

We have preferred in a first time to review a deep analysis on the crisis of subprime. Then we proceeded to analyze the foundations of stock markets as well as the impact of the crisis of subprime on the stock market and test theoretically the behavior of this crisis on these markets of a few European countries. Finally, we have put in empirical evidence this phenomenon of contagion by testing their existence through econometric methodologies parsimonious.

We found that this crisis is mainly a crisis of bank capital or there is a lack increased interbank liquidity outcome of the non-application of the prudential regulation rigid within the banks at the use of new financial products including the securitization of receivables.

Our empirical study shows the existence of the contagion and integration between the stock markets of a few European countries during the American crisis. For lead, we proceeded to the study of the correlation between the market in crisis (American) and the other markets during the period of crisis and the period of non-crisis. We have noticed a significant increase of the correlation coefficients between the different markets. This has allowed us to conclude that the periods of strong correlation are associated with periods of high volatility. However, an increase in the correlation between the markets of different countries is not sufficient to prove the existence of contagion as demonstrated in Forbes and Rigobon (2002). If the markets are historically related and inter correlated, a significant change in a market will naturally induce changes on the other markets and the correlations during crises can increase significantly.

For this reason, we have adopted a new procedure which is to test the non-linearity of the mechanisms of spread of estimated shocks through a model of interdependence in the long term VECM based on the test of cointegration (Test of Johenson). We have shown the existence of the cointegrating relationship between the series, justified after by a model 
VECM validated. Then, in order to know the country originating in crisis, we have used the test of causation in the Granger sense at the end to justify the presence of this kind of causality between the countries of our study. It can be reported that, during the period of crisis, the United States cause and the other countries including Germany, France and the United Kingdom.

\section{References}

[1] Agliette, M., (2008), "the crisis, why has it come to this? How to get out of it?" Editions Michalon, Paris, Pp. 21-58.

[2] Arvai, Zsofia and János Vincze, Janos (2000). "Financial Crises in transition countries: Models and facts" MNB Working Paper, (2000).

[3] Baig, T., Goldfajn, I., 1998. Financial market contagion in the asian crisis, IMF Working Paper, WP/98/155.

[4] Bekaert, G. Harvey, Q. C. and Ng, A. (2003), "Market Integration and contagion", NBER Working Paper, no. 9510.

[5] Billio, M., Pelizzon, L., 2003. Contagion and interdependence in stock markets: Have they been misdiagnosed? Journal of Economics and Business, 55, 405-426.

[6] Boyer, Robert, Dehove, Mario and PLIHON, Dominique (2004). "The financial crises", Council of Economic Analysis, $50,(2 \mathrm{OO} 4)$.

[7] Calvo, S., Reinhart, C., 1996. Capital flows to emerging countries: Is there evidence of contagion effects?, dans Calvo G., Goldestein M. et Hochreiter E. (éd.), Private capital flows to emerging markets, Institute for International Economics.

[8] Calvo, Guillermo (1999). "Contagion in Emerging Markets: When Wall Street is a Carrier", University of Maryland, (1999).

[9] Cartabinis, André (2004). "The triggering of the foreign exchange crises: what have we learned since ten years? International Economics, 97, (2004), 43p.

[10] Caporale, G. M., Cipollini, A., Spagnolo, N., 2005. Testing for contagion: a conditional correlation analysis, Journal of Empirical Finance, 12, 476-489.

[11] Cerra, V., Saxena, S., 2000. Contagion, monsoons and domestic turmoil in Indonesia: A case study in the Asian currency crises, IMF Working Paper, WP/00/60.

[12] Climent, F., Meneu, V., 2003. Has 1997 Asian crisis increased information flows between international markets, International Review of Economics and Finance, 12, 111-143.

[13] Dehove, Mario (2003). "Financial Crises two or three things that we know of them", Working Document, Council of Economic Analysis, (2003).

[14] Dungey, M., Zhumabekova, D., 2001. Testing for contagion using correlation: some words of caution, Pacific Basin Working Paper Series, $n^{\circ}$ PB01-09.

[15] Dornbuch, Rudiger and Chul Park Yung and Claessens Stijn (2000). "Contagion: how it spreads and how bed can be stopped", forthcoming World Bank Research observe, (2000).
[16] Engel, R. F., Granger, C. W. J., 1987. Co-integration and error correction representation, estimation and testing, Econometrica, 55, 251-276.

[17] Escribano, A., Pfann, A. G., 1998. Non-linear error correction, asymmetric adjustment and cointegration, Economic Modelling, 15, 197-216.

[18] Favero, C. A., Giavazzi, F., 2000. Looking for contagion: Evidence from the ERM, NBER Working Paper Series, 7797.

[19] Forbes, K., Rigobon, R., 2001. Contagion in Latin America: Definition, Measurement, and Policy Implications, Mit-Sloan school of management and NBER, January 17.

[20] Forbes, K., Rigobon, R., 2002. No contagion, only interdependence: Measuring stock market co-movements, Journal of Finance, 57 (5), 2223-2261.

[21] Gerlach, S., Smets, F., 1995. Contagious Speculative Attacks, European Journal of Political Economy, 11, 45-63.

[22] Glick, R., Rose, A. K., 1999. Contagion and trade - Why are currency crises regional, Journal of International Money and Finance, 18, 603-617.

[23] Glick, Reuven and pink, Andrew (1999). "Contagion and trade: Why are currency crises Regional? logging of International Money and Finance, 18, (1999), 14 p.

[24] Gilmore, C. G. and McManus, G. M. (2002), "international portfolio diversification: US and Central European equity markets", Emerging Markets Review, Vol. 3, Pp. 69-83

[25] Goldestein, I., Pauzner, A., 2004. Contagion of self-fulfilling financial crises due to diversification of investment portfolios, Journal of Economic Theory, 119, 151-183.

[26] Goldestein, M., 1998. The Asian financial crises: causes, cures and systemic implication, Policy Analysis in International Economics, Institute for International Economics, p.55.

[27] Granger, C. W. J., Lee, T. H., 1989. Investigation of production, sales and non-symmetric error correction models, Journal of Applied Econometrics, 4, 145-159.

[28] Gravelle, T., Kichian, M., Morley, J., 2005. Detecting shift contagion in currency and bond markets, Journal of International Economics.

[29] IMF, (2008 a), "Global Financial Stability Report, containing systemic risks and restoring financial soundness," MFIS Multimedia Services Division, April.

[30] IMF, (2008 b) "The global crisis and sub-Saharan Africa", African department.

[31] IMF, (2008 c), "the prospects for the world economy: financial turmoil, slowdowns and Adjustments", November.

[32] IMF, (2009 a) "The prospects for the world economy: Update of the main Projections", January.

[33] IMF, (2009 b), "Report on financial stability in the worldnews of the markets", January.

[34] Instability of the International Financial System (by OLLIVIER DAVANNE), the French documentation [1997].

[35] Irwin, Gregor. And vines David (1999). "A Krugman - Dooley - Sachs third generation model of the Asian financial crisis," Economic and Social Research Council (ESRC) - Global Economic Institutions, Working Paper Series, 46, (1999). 
[36] Kaminsky, G., Reinhart, C., 2000. On crises, contagion and confusion, Journal of International Economics, 51, 145-168.

[37] Kaminsky, Graciela and Reinhart, Carmen (1999). "The twin crises: the causes of banking and balance of payments problems", American Economic Review, 89, (1999), 3 p.

[38] Kaminsky, G., Linzondo, S., Reinhart, C., 1998. Leading indicators of currency crises, IMF Staff Papers, 45 (1).

[39] Kwiatkowski, D., Phillips, P. C. B., Schmidt, P., Shin, Y., 1992. Testing the Null Hypothesis of Stationarity Against the Alternative of a Unit Root. How Sure Are We that Economic Time Series Have a Unit Root? Journal of Econometrics, 54, 159-178.

[40] Khalid, A. M., Kawai, M., 2003. Was financial market contagion the source of economic crisis in Asia? Evidence using a multivariate VAR model, Journal of Asian Economics, 14, 131-156.

[41] King, M., Wadhwani, S., 1990. Transmission of volatility between stock markets, Review of Financial Studies, 3 (1), 5-33.

[42] King, M., Wadhwani, S., (1990). Transmission of volatility between stock markets. Review of Financial Studies 3, 5-33.

[43] Kordes, Laura and Pritsker, Matthew. "A rational expectations model of

[44] Krugman, Paul. "A Model of balance of payments crises," Journal of Money, Credit and Banking, 11, (1979), 14p.

[45] MacKinnon, J., 1991. Critical Values for Cointegration Tests, dans Long-Run Economic Relationships, Engle R. \& Granger C. (éd.), Oxford University Press.

[46] Marais, E., Bates, S., 2005. An empirical study to identify shift contagion during the Asian crisis, Journal of International Financial Markets, Institutions \& Money, à paraître.

[47] Masih, A. M. M., Masih, R., 1999. Are Asian stock market fluctuations due mainly to intra-regional contagion effects ? Evidence based on Asian emerging stock markets, PacificBasin Finance Journal, 7, 251-282.

[48] Masson, Paul R., 1999. Contagion: macroeconomic models with multiple equilibria, Journal of International Money and Finance, 18, 587-602.

[49] McAleer, M., Wei Nam, J. C., 2005. Testing for contagion in ASEAN exchange rates, Mathematics and Computers in Simulation, 68, 519-527.

[50] Obstfeld, Maurice, 1994. The logic of Currency crises, Banque de France, Cahiers économiques et monétaires, Banque de France, $n^{\circ} 43$.
[51] Osterwald-Lenum, M., 1992. A note with Quantiles of the Asymptotic Distribution of the Maximum likelhood Cointegration Rank Test Statistics, Oxford Bulletin of Economics and Statistics, 54, 461-472.

[52] Park, Y. C., Song, C.-Y., 2001. Institutional Investor, Trade Linkage, Macroeconomic Similarities, and Contagion of the Thai crisis, Journal of the Japanese and International Economies, 15, 199-224.

[53] Rigobon, Roberto, 2000. A simple test for stability of linear models under heteroskedasticity, omitted variable, and endogenous variable problems, MIT Working Paper.

[54] Rigobon, Roberto, 2002. Identification through Heteroskedasticity, Mit-Sloan school of management and NBER, June, 20.

[55] Rigobon, Roberto, 2003. On the measurement of international propagation of shocks: is the transmission stable? Journal of International Economics, 61, 261-283.

[56] Sander, H., Kleimeier, S., 2003. Contagion and causality: an empirical investigation of four Asian episodes, Journal of International Financial Markets, Institutions \& Money, 13, 171-186.

[57] Tan, J. A. R., 1998. Contagion effects during the Asian financial crisis: Some evidence from stock price data, Pacific Basin Working Paper Series N ${ }^{\circ}$ 98-06.

[58] Tobias, Adrien (2008). "Liquidity and contagion", Financial Stability Review, Bank of France, 11, (2008).

[59] Van Rijckeghem, Caroline and Weder, Beatrice (2000). "Financial contagion: Spillovers through banking centers", the contagion conference, (2000).

[60] Van Rijckeghem, C., Weder, B., 2001. Source of contagion: is it finance or trade, Journal of International Economics, 54, 293-308.

[61] Van Rijckeghem, C., Weer, B., 2003. Spillovers through banking centers: a panel data analysis of bank flows, Journal of International Money and Finance, 22, 483-509.

[62] Wälti, Sébastien, 2003. Testing for contagion in international financial markets: which way to go? HEI Working Paper 04/2003.

[63] ZouariI, Samir (2005). "Models of financial crises, indicators of vulnerability and involvement of the banking sector in the Asian crisis of 1997 - 1998", PHD thesis in Economic Sciences, University of Paris II Assas, (2005). 